\title{
Evaluation of the euthanasia of seropositive dogs for canine visceral leishmaniasis as the only method of controling the disease in the enzootic area in the Midwestern Minas Gerais ${ }^{1}$
}

Talita Pereira Vaz ${ }^{2,3}$, Marcella Oliveira Gama-Melo², Patrícia Flávia Quaresma ${ }^{3}$, Célia Maria Ferreira Gontijo ${ }^{3}$, Gilmar Santos ${ }^{4}$, Fernando Sérgio Barbosa ${ }^{5}$ and Gilberto Fontes ${ }^{2 *}$

\begin{abstract}
Vaz T.P., Gama-Melo M.O., Quaresma P.F., Gontijo C.M.F., Santos G., Barbosa F.S. \& Fontes G. 2020. Evaluation of the euthanasia of seropositive dogs visceral canine leishmaniasis as the only method of controling the disease in the enzootic area in the Midwestern Minas Gerais. Pesquisa Veterinária Brasileira 40(2):107-112. Universidade Federal de São João Del Rei, Rua Sebastião Gonçalves Coelho 400, Chanadour, Campus Centro Oeste, Divinópolis, MG 35501-296, Brazil. E-mail: gfontes@ufsj.edu.br

Human Visceral Leishmaniasis (VL) is expanding, and it is distributed in the five geographic regions of Brazil, with the Northeast being the region that presents the most significant number of registered cases. The main urban reservoir of the etiological agent of VL is the domestic dog, and it is known that canine cases precede human cases. One of the control actions of VL, recommended by the Ministry of Health, is performing the euthanasia of seropositive dogs. In 2013, in the municipality of Iguatama/MG, the first canine serological survey was carried out in the city, with a prevalence of $8.3 \%$ of seropositive dogs for Leishmania infantum. Of the seropositive animals for Canine Visceral Leishmaniasis (CVL) in this survey, 84\% were euthanized, and $16 \%$ died within two years after diagnosis. No other control measures for CVL were taken in the municipality. The objectives of the present study were to determine the current prevalence of seropositive dogs for CVL in the municipality of Iguatama and to observe the impact of euthanasia of seropositive dogs to VL as the only control measure performed in this municipality, which is considered an enzootic area of the disease. For this, a new canine epidemiological survey was carried out in the municipality of Iguatama, following the guidelines of the Manual of Surveillance and Control of Visceral Leishmaniasis. Blood samples were collected from 270 dogs and tested by DPP ${ }^{\circledR}$ immunochromatographic test and by Enzyme-Linked Immunosorbent Assay (ELISA). The animals that presented inconclusive results had new blood samples collected and analyzed. The only animal that showed a positive result in $\mathrm{DPP}^{\circledR}$ and undetermined in the ELISA, in the first evaluation, became seropositive four months later, so this study reinforces the recommendation of the Ministry of Health to reassess dogs that present inconclusive results for CVL. From a total of 270 samples, $21(7.8 \%)$ were reagents in both tests. Thus, the prevalence of seropositive dogs for CVL, in 2017, in the urban area of the municipality of Iguatama was 7.8\%. The Polymerase Chain Reaction-Restriction Fragment Length Polymorphism (PCR-RFLP) molecular technique confirmed infection by L. infantum in the ten dogs sampled with CVL-positive serology.
\end{abstract}

\footnotetext{
${ }^{1}$ Received on August 13, 2019.

Accepted for publication on October 11, 2019.

${ }^{2}$ Universidade Federal de São João Del Rei (UFSJ), Campus Centro Oeste, Rua Sebastião Gonçalves Coelho 400, Divinópolis, MG 35501-296, Brazil. *Corresponding author: gfontes@ufsj.edu.br

${ }^{3}$ Instituto René Rachou, Fundação Oswaldo Cruz (Fiocruz Minas), Av. Augusto de Lima 1715, Barro Preto, Belo Horizonte, MG 30190-009, Brazil.
}

\footnotetext{
${ }^{4}$ Superintendência Regional de Saúde (SRS) Divinópolis, Secretaria Estadual de Saúde, Av. Antonio Olímpio de Morais 2100, São Sebastião, Divinópolis, MG 35500-071.

${ }^{5}$ Centro Universitário de Formiga, Av. Doutor Arnaldo de Senna, 328, Água Vermelha, Formiga, MG, 35570-000, Brazil.
} 
The comparison between the current prevalence (after euthanasia) with that found in 2013 $(8.3 \%)$, there was no significant difference $(\mathrm{p}=0.764)$. The prevalence of CVL in the urban area of the municipality of Iguatama is still high, making it possible to presume that the euthanasia of seropositive dogs for CVL, and the absence of monitoring or other interventions measures, did not contribute to decrease the transmission of the parasite and was not sufficient for the control of CVL in the municipality of Iguatama, an area considered as non-endemic to CVL until 2013.

INDEX TERMS: Evaluation, euthanasia, seropositive, dogs, canine visceral leishmaniasis, control, enzootic area, Midwest, Minas Gerais, Brazil, Leishmania infantum, parasitic.

RESUMO.- [Avaliação da eutanásia de cães soro reagentes para leishmaniose visceral canina como único método de controle da doença em área enzoótica no Centro Oeste de Minas Gerais.] A Leishmaniose visceral humana (LV) está em franca expansão e distribuída nas cinco regiões geográficas do Brasil, o Nordeste sendo a região em que há o maior número de casos registrados. 0 principal reservatório urbano do agente etiológico da LV é o cão doméstico e sabe-se que casos caninos antecedem o aparecimento de casos humanos. Uma das ações de controle da LV, preconizada pelo Ministério da Saúde, é a eutanásia dos cães soro reagentes. Em 2013, no município de Iguatama/MG, foi realizado o primeiro inquérito sorológico canino na cidade, sendo constatada uma prevalência de 8,3\% de cães soro reagentes para Leishmania infantum. Dos animais com sorologia positiva para Leishmaniose visceral canina (LVC), neste inquérito, 84\% foram eutanasiados e 16\% foram a óbito em, no máximo, dois anos após o diagnóstico. Nenhuma outra medida de controle para LVC foi realizada no município. Os objetivos deste estudo foram determinar a prevalência atual de cães soro reagentes para LVC no município de Iguatama e observar o impacto das eutanásias de cães soro reagentes para LV como única medida de controle realizada neste município, considerado área enzoótica para a doença. Para isso, foi realizado um novo inquérito epidemiológico canino no município de Iguatama, seguindo as normas do Manual de Vigilância e Controle da Leishmaniose Visceral. Foram colhidas amostras sanguíneas de 270 cães que foram examinadas pelo teste imunocromatográfico $\mathrm{DPP}^{\circledR}$ e pelo ensaio imunoenzimático (ELISA). Os animais que apresentaram resultados inconclusivos tiveram novas amostras de sangue coletadas e analisadas. $O$ único animal que apresentou resultado positivo no DPP ${ }^{\circledR}$ e indeterminado no ELISA, na primeira avaliação, soro converteu quatro meses depois, o que reforça a recomendação do Ministério da Saúde de reavaliar os cães que apresentam resultado inconclusivo para LVC. Do total das 270 amostras, 21 foram reagentes nos dois testes. Portanto, a prevalência de cães soro reagentes para LVC, em 2017, na área urbana do município de Iguatama foi igual a 7,8\%. A infecção pela espécie Leishmania infantum foi confirmada através da técnica molecular de PCR-RFLP em 10 cães amostrados com sorologia positiva para LVC. A comparação entre a prevalência atual (depois das eutanásias) com a encontrada em 2013 (8,3\%), não mostrou diferença significativa $(p=0,764)$. Uma vez que a soro prevalência de LVC na área urbana do município de Iguatama ainda é alta, pode-se supor que a eutanásia dos cães soro reagentes para LVC, somada à ausência de monitoramento e de outras medidas de intervenção, não contribuiu para a diminuição da transmissão do parasito, e não foi suficiente para o controle de LVC no município de Iguatama, uma área considerada, até 2013, indene para LVC.

TERMOS DE INDEXAÇÃO: Avaliação, eutanásia, cães soro reagentes, leishmaniose visceral canina, método de controle, área enzoótica, Leishmania infantum, caninos, Centro Oeste, Minas Gerais, Brasil, parasitoses.

\section{INTRODUCTION}

Visceral leishmaniasis (VL) is part of a group of diseases considered neglected by the World Health Organization (WHO), with an estimated 200,000 to 400,000 new human cases per year worldwide (Alvar et al. 2012, WHO 2018). The disease has high mortality when untreated, and there is a higher risk for late-diagnosed cases, inadequately treated cases, and immunosuppressed or drug-resistant individuals (Marzochi et al. 2014, WHO 2015). Transmission occurs through the bite of females of phlebotomine insects infected by protozoan species Leishmania infantum (WHO 2015).

In Brazil, the domestic dog (Canis familiaris) is the main reservoir of the etiologic agent of VL in urban areas (Gontijo \& Melo 2004, Dantas-Torres 2006), being the most prevalent canine infection than the human one (Brasil 2014). Canine visceral leishmaniasis (CVL) cases precede human cases (Bevilacqua et al. 2001, Brasil 2014, Teixeira-Neto et al. 2014). Infection among dogs spreads rapidly in the presence of excellent conditions for transmission, such as the high density of vector insects and susceptible dogs, and the seroprevalence of dogs with VL is considerably higher than the prevalence of sick animals (Baneth et al. 2008). The asymptomatic and oligosymptomatic dogs are also capable of infecting the insect vectors of the etiologic agent of VL (Michalsky et al. 2007, Marcondes \& Rossi 2013).

Prior knowledge of the infection in dogs serves as a warning for the beginning of control actions to prevent the occurrence of human cases. Control methods for VL in Brazil are explicit in the Visceral Leishmaniasis Control Program (VLCP), and among them is the euthanasia of seropositive dogs for CVL (Brasil 2014). Oppositions against this action and the debate about the affective and economic value of dogs have gained more and more strength, supported by studies suggesting more effective control measures (Costa 2011, Werneck et al. 2014, Shimozako et al. 2017).

The municipality of Iguatama, located in the Midwest region of the state of Minas Gerais (MG), recorded its first authocthonous case of CLV in 2013 (Faria et al. 2017) and has not yet reported any human cases of VL (DATASUS-SINAN-MS 2018). In 2013, the State Department of Health of Minas Gerais conducted an entomological survey in the city and found 
specimens of insects of the species Lutzomyia longipalpis. In the same year, a canine sample epidemiological survey was carried out and found a prevalence of $8.3 \%$ of CVL in the urban area of the city, and after conducting the survey, $84 \%$ of the serum reagent dogs found were euthanized (Faria 2014) and $16 \%$ died within two years of diagnosis (Vaz 2018). No other control measures for VL were adopted in the municipality.

Given the difficulties in controlling VL, it is crucial to analyze the control methods employed, mainly from the euthanasia of seropositive dogs, which is the most practiced control action today. The objective of this study was to reevaluate the seroprevalence of CVL in Iguatama/MG, and to observe the impact of euthanasia of VL-seropositive dogs as the only control measure performed in this municipality, considered an enzootic area for the disease.

\section{MATERIALS AND METHODS}

The study was approved by the Animal Use Ethics Committee of Universidade Federal de São João Del Rei (UFSJ) (protocol no. 28/2016). It is about a cross-sectional study by stratified sampling, held from April to August 2017 in the urban area of the municipality of Iguatama, the first city bathed by the São Francisco river, located in the Midwest of Minas Gerais. Its territorial area is $628.2 \mathrm{~km}^{2}$ and is limited to the municipalities of Arcos, Doresópolis, Luz, and Bambuí (IBGE 2016). In 2016, according to the census conducted by the Instituto Brasileiro de Geografia e Estatística (IBGE), the total population (urban and rural) of Iguatama was estimated at 8,182 inhabitants (IBGE 2016). According to data from the Geographic Reference System (GRS) of the Unified Health System (UHS), the urban population of Iguatama in March 2017 was 6,765 inhabitants.

To estimate the size of the canine population in the municipality of Iguatama/MG, data from the anti-rabies vaccination campaign in the city of 2017 were used, which determine a canine population of approximately $13.5 \%$ of the human population. Based on this, it was possible to estimate that the dog population in the urban area is about 913 animals. It is estimated that in the urban area of the city, there is approximately one dog for 7.4 people. Knowing that the vaccination coverage of the rabies campaign is approximately $90 \%$ of the animals, the number of dogs in the urban area of the municipality of Iguatama to be considered in the study goes from an estimated 913 to approximately 1,000 dogs.

A canine sample survey was conducted to determine the current prevalence of CVL in the municipality, as recommended by the Visceral Leishmaniasis Surveillance and Control Manual for municipalities with a canine population of over 500 animals (Brasil 2014). The table 1 from the Visceral Leishmaniasis Surveillance and Control Manual (Brasil 2014) was used to calculate the sample size to be obtained, according to the estimated dog population and the expected CVL prevalence considering a significance level of 5\% (Brasil 2014).

Knowing the estimated number of dogs in the urban area, approximately 1,000 animals, and the previous prevalence of CVL found in the city was $8.3 \%$ (Faria 2014), a total of 159 dogs should be sampled in the municipality of Iguatama, according to the table in the Visceral Leishmaniasis Surveillance and Control Manual (Brasil 2014). However, following the epidemiological survey for CVL conducted in 2013, 84\% of seropositive dogs were euthanized (Faria 2014). Whereas euthanasia of serum dogs reagents for CVL is one of the disease control measures (Brasil 2014), it would be expected that the prevalence of CVL in the municipality had decreased after 2013. It was estimated for the current study a prevalence of 3.1\% to $4 \%$ of CVL in the municipality of Iguatama, and considering the canine population maintained around 1,000 animals, the sample used in the study for 270 dogs (Brasil 2014).

Neighborhoods stratified the sample and worked by conglomerates that corresponded to the blocks. From each block, $50 \%$ of the properties were worked, with a maximum of two dogs per property, to ensure a better distribution of the sample. In April 2017, the 270 dogs were examined, from which $4 \mathrm{~mL}$ of cephalic or jugular vein blood was collected. The collected blood was immediately deposited in a tube containing a clot activator and identified with the dog's name and dog number in the sample. The samples were centrifuged at $3,000 \mathrm{~g}$ for 10 minutes to separate the serum, which was transferred to $1.5 \mathrm{~mL}$ microtubes identified with the dog number in the sample and stored at $-20^{\circ} \mathrm{C}$ until the serological tests were performed. Also, bone marrow aliquots were collected from 10 dogs with CVL-positive serology included in the sample for molecular diagnostic methods. The dogs also underwent a clinical evaluation by the veterinarian responsible for the study.

The Ministério da Saúde (MS) determines two immunologic tests for the diagnosis of CVL: Dual Path Platform (DPP ${ }^{\circledR}$ ) immunochromatographic test as screening and confirmation by the ELISA enzyme immunoassay. In this study, all 270 samples were tested by DPP ${ }^{\circledR}$ and ELISA, and both tests were performed at the Laboratório de Parasitologia of UFSJ, which is accredited with the Fundação Ezequiel Dias as a regional reference for the diagnosis of CVL in the Midwest of Minas Gerais State. To conclude both tests, kits produced by Biomanguinhos/Fiocruz were used, following the manufacturer's recommendations.

Animals that showed inconclusive results (DPP ${ }^{\circledR}$ reagent and undetermined ELISA or DPP ${ }^{\circledR}$ nonreactive and reagent or undetermined ELISA results) had new blood samples collected and analyzed four months after the first collection. The reevaluation of these dogs followed the same protocol as the first evaluation.

Aliquots of $300 \mu \mathrm{L}$ of bone marrow from dogs with positive serology for CVL were used as a DNA source for molecular tests. The Internal Transcribed Spacer-1 (ITS-1) PCR-RFLP technique (Schonian et al. 2003) was employed to identify the Leishmania species responsible for the infection of the ten dogs sampled with CVL-positive serology.

Statistical calculations were performed using the OpenEpi software, version 3.01, and the Yates-corrected Chi-square test, which was used to compare prevalence.

\section{RESULTS}

Of the 270 dogs evaluated, 20 were reagents for CVL in both serological tests, and 11 showed inconclusive results. After a reassessment of 11 inconclusive serums, only one of them, the only one that showed reagent results in $\mathrm{DPP}^{\circledR}$ and undetermined in ELISA, became reagent in both tests. Thus, the seroprevalence of CVL in the municipality of Iguatama in 2017 was $7.8 \%$, e.g., 21 of the 270 dogs that were seropositive for CVL. 
Most CVL seropositive dogs (58\%) were up to four years old. Most of them were symptomatic 17/21 (81\%), and the most frequently observed clinical signs were: onychogryphosis (48\%), weight loss (38\%), and hypocolored mucosa (38\%).

There was no significant difference between the CVL seroprevalence found in the urban area in the municipality of Iguatama in the first survey conducted in 2013 (8.3\%) (Faria 2014), with the CVL seroprevalence found in 2017, four years after euthanasia $(7.8 \%)(p=0.764)$.

The ITS-1 PCR-RFLP results showed that all ten dogs presented positive PCR by analysis of bone marrow material, being infected by L. infantum, corroborating the presence of a large number of CVL-seropositive animals in the municipality of Iguatama.

\section{DISCUSSION}

Maintaining high serum CVL prevalence in the municipality of Iguatama, as found in this study, serves as a warning to health professionals and local authorities about the need for more efficient CVL control measures in the municipality. The prevalence of CVL in Iguatama today is similar to that found in the Paraíba semi-arid region of northeastern Brazil (Silva et al. 2016), a geographical region with the highest prevalence of Human Visceral Leishmaniasis (HVL) and CVL in the country (Bavia et al. 2005).

Cases of CVL are known to precede human cases of the disease (Bevilacqua et al. 2001, Brasil 2014, Teixeira-Neto et al. 2014). Florianópolis, in the state of Santa Catarina (SC), recorded its first autochthonous case of CVL in 2012 (Figueiredo et al. 2012), and in 2017 the first two autochthonous cases of the disease in humans (SMSF 2017, SBMT 2017), showing the previous occurrence of cases of the disease in dogs. It is also important to note the short time elapsed between autochthonous cases of CVL and HVL. The municipality of Iguatama has not yet reported any cases of HVL but is vulnerable, and human cases and deaths from the disease may be occurring that were not correctly diagnosed, and therefore, not reported.

Given the importance of dogs as a reservoir of L. infantum in the urban environment, and the recommendation to perform euthanasia of seropositive dogs for VL, the correct diagnosis of canine infection becomes crucial.

The current study confirms the recommendation of the MS to reassess dogs with reagent results in DPP ${ }^{\circledR}$ and undetermined in ELISA, therefore, the only dog in the sample that presented this result, serum converted four months after the first evaluation. Lopes et al. (2017) observed that the serological protocol has a low detection capacity of $L$. infantum when compared with the molecular method (PCR) yet has good ability to identify infected animals correctly. In fact, in this study, we were able to confirm L. infantum infection in a sample of ten dogs out of a total of $21 \mathrm{CVL}$ positive serum animals in both serological methods employed. This result is significant to reinforce that most serum reagent dogs are indeed infected with $L$. infantum therefore, they are reservoir hosts that act as a source of infection for the sand fly vectors, contributing to the maintenance of the parasite in the studied area.

Most of the seropositive dogs were symptomatic, which is consistent with the findings of Mendonça et al. (2017). $\mathrm{DPP}^{\circledR}$ test sensitivity is known to be higher in symptomatic dogs (Grimaldi Junior et al. 2012). This characteristic of the test may explain that most of the CVL-seropositive dogs found in the municipality of Iguatama are symptomatic. In symptomatic dogs, onychogryphosis, weight loss, and mucosa were more frequently observed, findings consistent with Silva et al. (2017).

The absence of a significant difference between the prevalence of CVL in Iguatama in 2013 and 2017, together with the lack of monitoring and other control measures in the municipality, suggests that the euthanasia of seropositive dogs did not contribute to reducing the prevalence of CVL in the county. A study conducted by Werneck et al. (2014) in Northeastern Brazil, reported from low to moderate the effectiveness of euthanasia of dogs with CVL as a control measure of VL, and an urgent need for revision of the Brazilian Program for Control of the disease.

In a systematic review commissioned by the Pan American Health Organization (PAHO) to evaluate VL control actions it is concluded that there is no firm evidence of a significant impact of the interventions analyzed on VL transmission, and although, canine euthanasia is the least acceptable intervention from the community point of view and has low efficiency due to the replacement of dogs eliminated by susceptible dogs (Romero \& Boelaert 2010). Shimozako et al. (2017) when assessing the impact of five VL control measures on the human and canine population, taking into account epidemiological control and the cost-effectiveness observed that the use of insecticide collar in dogs presented the best association between disease control and cost-effectiveness, and should be the first choice among VL control strategies. Regarding the euthanasia of VL- seropositive dogs as a disease control measure, Shimozako et al. (2017) observed that when dog mortality is intensified, canine population renewal also occurs.

The mean age of the dogs sampled (four years) was equal to the time interval between the two canine surveys performed, and most VL reagent dogs in this study were up to four years old. These dogs may have been replacing the dog's serum eliminated reagents. According to Oliveira \& Araújo (2003), the immediate replacement of dogs with eliminated CVL, performed by the human population, compromises the efficiency of euthanasia in seropositive dogs for CVL as a disease control measure.

Nunes et al. (2008) in a study conducted in an endemic area for CVL in Brazil found that about $40 \%$ of dogs were replaced with an average time of four months, and at nine months of follow-up of the replacement dogs, $42 \%$ of them were already serum reagents for CVL. The euthanasia of dogs with CVL seems to influence the structure of the canine population rather than its size, leading to the increase in the young portion of the canine population that may also have severe epidemiological consequences on other diseases, such as rabies, because these animals may not be vaccinated (Andrade et al. 2007).

Educational actions directed to the population should accompany euthanasia of serum dogs reacting to CVL. In endemic areas, responsible tenure programs may be more useful for VL control than canine population control means (Andrade et al. 2007). In the municipality of Iguatama, no educational actions were carried out at any time, which may have impaired the effectiveness of euthanasia as a method of controlling CVL. 


\section{CONCLUSIONS}

The prevalence of CVL in the municipality of Iguatama is still high and has not changed since the first canine survey conducted in 2013, which led to the euthanasia of seropositive dogs for CVL.

It may be suggested that the euthanasia of seropositive dogs, with the lack of monitoring and other control measures, did not contribute to a decrease in CVL seroprevalence in the municipality of Iguatama.

Acknowledgments.- To the "Prefeitura Municipal de Iguatama" for the support for the work, Natália Oliveira Rodrigues, for the participation in the fieldwork.

\section{This study was funded by Programa INOVA Fiocruz and CNPq (Universal} 429253/2018-4). CMFGontijo is research fellow from CNPq.

Conflict of interest statement.- The authors have no competing interests.

\section{REFERENCES}

Alvar J., Vélez I.D., Bern C., Herrero M., Desjeux P., Cano J., Jannin J., den Boer M., \& WHO Leishmaniasis Control Team 2012. Leishmaniasis worldwide and global estimates of its incidence. PLoS One 7(5):e35671. <http:// dx.doi.org/10.1371/journal.pone.0035671><PMid:22693548>

Andrade A.M., Queiroz L.H., Nunes G.R., Perri S.H.V. \& Nunes C.M. 2007. Reposição de cães em área endêmica para leishmaniose visceral. Revta Soc. Bras. Med. Trop. 40(5):594-595. <http://dx.doi.org/10.1590/S003786822007000500021>

Baneth G., Koutinas A.F., Solano-Gallego L., Bourdeau P. \& Ferrer L. 2008. Canine leishmaniosis - new concepts and insights on an expanding zoonosis: part one. Trends Parasitol. 24(7):324-330. <http://dx.doi.org/10.1016/j. pt.2008.04.001 ><PMid:18514028>

Bavia M.E., Carneiro D.D., Gurgel H.C., Madureira Filho C. \& Barbosa M.G. 2005. Remote sensing and geographic information systems and risk of American visceral leishmaniasis in Bahia, Brazil. Parassitologia 47(1):165169. <PMid:16044686>

Bevilacqua P.D., Paixão H.H., Modena C.M. \& Castro M.C.P.S. 2001. Urbanização da leishmaniose visceral em Belo Horizonte. Arq. Bras. Med. Vet. Zootec. 53(1):1678-4162.<http://dx.doi.org/10.1590/S0102-09352001000100001>

Brasil. Ministério da Saúde. 2014. Manual de Vigilância e Controle da Leishmaniose Visceral. Ministério da Saúde, Brasília, DF. 122p.

Costa C.H.N. 2011. How effective is dog culling in controlling zoonotic visceral leishmaniasis? A critical evaluation of the science, politics and ethics behind this public health policy. Revta Soc. Bras. Med. Trop. 44(2):232-242.<http:// dx.doi.org/10.1590/S0037-86822011005000014> <PMid:21468480>

Dantas-Torres F. 2006. Situação atual da epidemiologia da leishmaniose visceral em Pernambuco. Revta Saúde Públ. 40(3):537-541. <http://dx.doi. org/10.1590/S0034-89102006000300024>

DATASUS-SINAN-MS 2018. Leishmaniose visceral - casos confirmados segundo ano notificação - município de residência: Iguatama. Sistema de Informação de Agravos de Notificação 2017, Tecnologia da Informação a Serviço do SUS, Ministério da Saúde, Brasília, DF. Available at <http:// tabnet.datasus.gov.br/cgi/tabcgi.exe?sinanwin/cnv/leishvmg.def> Access on May 14, 2018.

Faria M.T. 2014. Prevalência de leishmaniose canina no município de IguatamaMG, utilizando diagnóstico imunológico. Master's Thesis, Universidade Federal de São João Del Rei, Campus Centro-Oeste, Divinópolis. 97p.

Faria M.T., Barbosa F.S., Teixeira-Neto R.G., Pinheiro G.R.G., Manhani M.M., Marcelino A.P., Barbosa J.R. \& Fontes G. 2017. Autochthonous case of Canine Visceral Leishmaniasis in a non-endemic area in Minas Gerais,
Brazil. Pesq. Vet. Bras. 37(12):1505-1508. <http://dx.doi.org/10.1590/ s0100-736x2017001200023>

Figueiredo F.B., Lima F.E.F., Tomio J.E., Indá F.M.C., Corrêa G.L.B. \& Madeira M.F. 2012. Leishmaniose Visceral Canina: dois casos autóctones no município de Florianópolis, Estado de Santa Catarina. Acta Scient. Vet. 40:1026-1030.

Gontijo C.M.F. \& Melo M.N. 2004. Leishmaniose visceral no Brasil: quadro atual, desafios e perspectivas. Revta Bras. Epidemiol. 7(3):338-349. <http:// dx.doi.org/10.1590/S1415-790X2004000300011>

Grimaldi Junior G., Teva A., Ferreira A.L., Santos C.B., Pinto I.S., Azevedo C.T. \& Falqueto A. 2012. Evaluation of a novel chromatographic immunoassay based on Dual Path Platform technology (DPP ${ }^{\circledR}$ CVL rapid test) for the serodiagnosis of canine visceral leishmaniasis. Trans. R. Soc. Trop. Med. Hyg. 106(1):54-59. <http://dx.doi.org/10.1016/j.trstmh.2011.10.001> $<$ PMid:22137538>

IBGE 2016. Cidades: Iguatama. Instituto Brasileiro de Geografia e Estatística, Brasília, DF. Available at <http://cod.ibge.gov.br/18WG> Access on Jun. $30,2016$.

Lopes E.G., Sevá A.P., Ferreira F., Nunes C.M., Keid L.B., Hiramoto R.M., Ferreira H.L., Oliveira T.M.F.S., Bigotto M.F.D., Galvis-Ovallos F., Galati E.A.B. \& Soares R.M. 2017. Serological and molecular diagnostic tests for canine visceral leishmaniasis in Brazilian endemic area: one out of five seronegative dogs are infected. Epidemiol. Infect. 145(12):2436-2444. <http://dx.doi. org/10.1017/S0950268817001443><PMid:28726597>

Marcondes M. \& Rossi C.N. 2013. Leishmaniose visceral no Brasil. Braz. J. Vet. Res. Anim. Sci. 50(5):341-352. <http://dx.doi.org/10.11606/issn.23183659.v50i5p341-352>

Marzochi M.C.A., Marzochi K.B.F., Fagundes A. \& Conceição-Silva F. 2014. A questão do controle das leishmanioses no Brasil, p.432-463. In: ConceiçãoSilva F. \& Alves C.R. (Eds), Leishmanioses do Continente Americano. Fiocruz Editora, Rio de Janeiro.

Mendonça I.L., Batista J.F., Werneck G.L., Soares M.R.A., Costa D.L. \& Costa C.H.N. 2017. Serological tests fail to discriminate dogs with visceral leishmaniasis that transmit Leishmania infantum to the vector Lutzomyia longipalpis. Revta Soc. Bras. Med. Trop. 50(4):483-488. <http://dx.doi. org/10.1590/0037-8682-0014-2017> <PMid:28954069>

Michalsky É.M., Rocha M.F., da Rocha Lima A.C.V.M., França-Silva J.C., Pires M.Q., Oliveira F.S., Pacheco R.S., Santos S.L., Barata R.A., Romanha Á.J., Fortes-Dias C.L. \& Dias E.S. 2007. Infectivity of seropositive dogs, showing different clinical forms of leishmaniasis, to Lutzomyia longipalpis phlebotomine sand flies. Vet. Parasitol. 147(1-2):67-76. <http://dx.doi.org/10.1016/j. vetpar.2007.03.004 ><PMid:17449184>

Nunes C.M., Lima V.M.F., Paula H.B., Perri S.H.V., Andrade A.M., Dias F.E.F. \& Burattini M.N. 2008. Dog culling and replacement in an area endemic for visceral leishmaniasis in Brazil. Vet. Parasitol. 153(1-2):19-23. <http:// dx.doi.org/10.1016/j.vetpar.2008.01.005><PMid:18314275>

Oliveira S.S. \& Araújo T.M. 2003. Avaliação das ações de controle da leishmaniose visceral (calazar) em uma área endêmica do Estado da Bahia, Brasil (19952000). Cad. Saúde Públ. 19(6):1681-1690. <http://dx.doi.org/10.1590/ S0102-311X2003000600012>

Romero G.A.S. \& Boelaert M. 2010. Control of visceral leishmaniasis in Latin America: a systematic review. PLoS Negl. Trop. Dis. 4(1):e584. <http:// dx.doi.org/10.1371/journal.pntd.0000584><PMid:20098726>

SBMT 2017. Segundo caso autóctone de calazar é confirmado em Florianópolis. Sociedade Brasileira de Medicina Tropical, Brasília, DF. Available at <http://www.sbmt.org.br/portal/segundo-caso-autoctone-de-calazare-confirmado-em-florianopolis/> Access on Feb. 10, 2018.

Schonian G., Nasereddin A., Dinse N., Schweynoch C., Schallig H.D., Presber W. \& Jaffe C.L. 2003. PCR diagnosis and characterization of Leishmania in local and imported clinical samples. Diagn. Microbiol. Infect. Dis. 47(1):349-358. <http://dx.doi.org/10.1016/S0732-8893(03)00093-2><PMid:12967749> 
Shimozako H.J., Wu J. \& Massad E. 2017. The preventive control of zoonotic visceral leishmaniasis: efficacy and economic evaluation. Comput. Math. Methods Med. 2017:4797051.<http://dx.doi.org/10.1155/2017/4797051> <PMid:28588642>

Silva R.B.S., Mendes R.S., Santana V.L., Souza H.C., Ramos C.P.S., Souza A.P., Andrade P.P. \& Melo M.A. 2016. Aspectos epidemiológicos da leishmaniose visceral canina na zona rural do semiárido paraibano e análise de técnicas de diagnóstico. Pesq. Vet. Bras. 36(7):625-629.<http://dx.doi.org/10.1590/ S0100-736X2016000700011>

Silva K.R., Mendonça V.R.R., Silva K.M., Nascimento L.F.M., Mendessousa A.F., Pinho F.A., Barral-Netto M., Barral A.M.P. \& Cruz M.S.P. 2017. Scoring clinical signs can help diagnose canine visceral leishmaniasis in a highly endemic area in Brazil. Mem. Inst. Oswaldo Cruz. 112(1):53-62. <http:// dx.doi.org/10.1590/0074-02760160305><PMid:28076469>

SMSF 2017. Alerta epidemiológico: Leishmaniose Visceral Humana. Diretoria de Vigilância e Saúde, Gerência de Vigilância Epidemiológica, Secretaria Municipal de Saúde de Florianópolis, Florianópolis, SC. Available at <http://www.simesc.org.br/Handlers/ExibirArquivo.ashx?id=427818> Access on Nov. 11, 2017.
Teixeira-Neto R.G., Silva E.S., Nascimento R.A., Belo V.S., Oliveira C.L., Pinheiro L.C. \& Gontijo C.M.F. 2014. Canine visceral leishmaniasis in an urban setting of Southeastern Brazil: an ecological study involving spatial analysis. Parasit. Vectors 7(1):485. <http://dx.doi.org/10.1186/s13071-014-04857><PMid:25326767>

Vaz T.P. 2018. Reavaliação de uma área enzoótica para a leishmaniose canina no Centro Oeste de Minas Gerais. Master's Thesis, Universidade Federal de São João Del Rei, Campus Centro-Oeste, Divinópolis. 78p.

Werneck G.L., Costa C.H.N., Carvalho F.A.A., Cruz M.S.P., Maguire J.H. \& Castro M.C. 2014. Effectiveness of insecticide spraying and culling of dogs on the incidence of Leishmania infantum infection in humans: a cluster randomized trial in Teresina, Brazil. PLoS Negl. Trop. Dis. 8(10):e3172.<http://dx.doi. org/10.1371/journal.pntd.0003172 > <PMid:25357122>

WHO 2015. Leishmaniasis. World Health Organization, Genebra. Available at <http://www.who.int/leishmaniasis/visceral_le ishmaniasis/en/> Access on Jun. 10, 2016.

WHO 2018. Leishmaniasis, situation and trens. World Health Organization, Genebra. Available at <http://www.who.int/leishmaniasis/en//> Access on Sep. 5, 2017. 